\title{
METHODOLOGICAL ASPECTS OF SOCCER INITIATION IN ANDERLECHT -
} BELGIUM.

\author{
${ }^{1}$ Sergio Augusto Leite Figueira
}

\begin{abstract}
Introduction: RSC Anderlecht, a Belgian club, was founded in 1908 and headquartered in Anderlecht, a municipality in the Brussels region (Capital of Belgium) and is the most successful football club in that country. In its formation, Anderlecht became a legend far beyond the Belgian borders. Objective: To describe and disseminate the methodological paths used in the practice of soccer, in grassroots categories in RSC Anderlecht - Belgium. Method: This study was a descriptive experience report. Discussion: At Anderlecht, the training process for young athletes comes close to an active methodology, where physical, technical and tactical activities are always linked to cognitive issues, always seeking to develop the intelligence and creativity of these individuals. Conclusion: It is concluded that there is a dynamic and transversal methodology within the RSC Anderlecht, which seeks at the end of each cycle an evaluation, re-planning and redirection of all methodology that follows in an institution that values the initiation and development process of the individual in soccer. This means always seeking to update based on the evolution of methodological and pedagogical theories, finding answers and seeking new questions.
\end{abstract}

Keywords: Sport, soccer, initiation.

${ }^{1}$ RSC Anderlecht - Bélgica.

E-mail: sergioaugustolf@hotmail.com

\section{ASPECTOS METODOLÓGICOS DA INICIAÇÃO DO FUTEBOL NO ANDERLECHT - BÉLGICA}

\section{RESUMO}

Introdução: O RSC Anderlecht, clube Belga, foi fundado em 1908 e sediado em Anderlecht, município da região de Bruxelas (Capital da Bélgica) e é o clube de futebol mais bem-sucedido nesse país. Na sua formação, o Anderlecht tornou-se uma lenda muito além das fronteiras Belgas. Objetivo: Descrever e divulgar os caminhos metodológicos utilizados na prática do futebol, em categorias de base no RSC Anderlecht - Bélgica. Método: O referido estudo foi do tipo relato de experiência de forma descritiva. Discussão: No Anderlecht, o processo de formação dos jovens atletas aproxima-se de uma metodologia ativa, onde as atividades físicas, técnicas e táticas estão sempre atreladas às questões cognitivas, buscando sempre desenvolver a inteligência e a criatividade desses indivíduos. Conclusão: Conclui-se que existe dentro do RSC Anderlecht uma metodologia dinâmica e transversal, que busca ao final de cada ciclo uma avaliação, re-planejamento e re-direcionamento de toda metodologia que se segue numa instituição que valoriza o processo de iniciação e desenvolvimento do indivíduo no futebol. Isso significa buscar sempre atualização com a evolução das teorias metodológicas e pedagógicas, encontrar respostas e buscar novas perguntas.

Palavras-chave: Esporte, futebol, iniciação.

${ }^{1}$ RSC Anderlecht - Bélgica. 


\section{INTRODUCTION}

Belgium is a small country with an area of more than $30,000 \mathrm{~km} 2$ and a population that exceeds 11 million inhabitants; politically divided into two parts, the Wallonia (French language) and the Dutch-speaking (Flanders). The country is located in Western Europe, bordering Germany, France, Luxembourg and the Netherlands (the latter its great rival and mirror in the formation in soccer). As in the whole country, the practice of sport in general, is mandatory or not. In this sense, for Caldas et al., (2014) the sport phenomenon is that activity where children, youth, adults and the elderly are able to perform systematic physical exercises or not, giving meaning to this practice and their lives.

An example of a sport, soccer presents itself as one of the most motivating collective practices with children and young people from all over the world, encouraging them to live an active life in the future. In soccer, practitioners run, move, jump, know the shocks between bodies, try to balance themselves and solve the situational problems that arise. That is, playing soccer, the practitioner experiences and develops motor and cognitive skills that will contribute to the formation, who knows, of a future high-level / professional athlete (KIELING, 2016; GREBOGGY and SILVA, 2018).

RSC Anderlecht, a Belgian club, was founded in 1908 and headquartered in Anderlecht, a municipality in the Brussels region (Capital of Belgium). His motto is "Mens sana in corpore sano" and he is the most successful soccer club in that country. First promoted to the first Belgian division in 1921, a level that has not left since 1935, Anderlecht has five European trophies in its name: European Cup Winners' Cup and the European Super Cup, won in 1976 and 1978, as well as the World Cup UEFA in 1983. These successes ranked tenth in the ranking of 20th century European soccer clubs, according to the IFFHS and first in Belgium, far ahead of FC Brugge and Standard de Liège, their two main national rivals.

In its formation, RSC Anderlecht has become a legend far beyond the Belgian borders. To prepare the next generations and offer a high-level training site for its professional players, the club opened in 2011 a training center in Neerpede (Anderlecht municipality), covering $8,362 \mathrm{~m}^{2}$ and $2,700 \mathrm{~m}^{2}$ holding five natural grass and one synthetic grass training fields. It is worth noting that from the under 14 categories to the professional they work in these spaces and the under 6 to under 13 categories in the RSC Academy.
Some achievements of Anderlecht's formation are: UEFA Youth League; Semi-finalist in 2015, 2016, Viareggio Tournament; Winner in 2013, Finalist in 2014; AEGON Future Cup; Winner in 2011, 2013, 2015, NextGen Series; Winner in 2018.

Soccer in Belgium has been practiced since the late 19th century, being its most popular sport. The Belgian Football Federation Faith created in 1895, to bring some order and organization to the sport, the first game of the national team of faith, played on May 1, 1904 and the score of this meeting was 3 to 3 , against France. The first Belgian soccer championship, the Jupiler League, is one of the oldest in the world (official matches have been held since 1986). The first division is named like this because the main sponsor of the league is the Jupiler brewery and in this competition the most important teams are: RSC Anderlecht, Standard de Liège, Club Brugge KV and KRC Genk. All have between 19 and 25 thousand spectators, on average in their games.

Studies and discussions about soccer take place every day and from them arise methodological concerns regarding the teaching of this sport, especially in the grassroots categories, whether in a general or specific way. When it comes to the Bayer methodology (1994), there are two methodological currents (traditional and active) for teaching team sports. At Anderlecht we believe in a more active methodology, where practitioners develop their intelligence and creativity, not just mechanized technical gestures (CALDAS et al., 2012; DALLEGRAVE, BERNO, FOLLE, 2017; REVERDITO, SCAGLIA, 2009).

Since 2009 developing professional activities in Belgian soccer, specifically in Anderlecht, these concerns mentioned above have arisen. Therefore, this report is justified for discussing and evolving in relation to them, and aims to describe and disseminate the methodological paths used in the practice of soccer, in grassroots categories in that club.

\section{METHOD}

This study was of the descriptive experience type. The recruitment of young athletes at Anderlecht is carried out through the "Talent Day", an event held once a year, where parents register their children on the club's website up to the sub 10 category. The talent detection department watches games and training in other teams (observers), which Anderlecht maintains some partnerships with satellite clubs (agreement). The initiation at Anderlecht takes place from categories sub 6 
to sub 9 and works with both genders. In this report, specifically, aspects of the male department will be described.

The athlete's training is divided as follows: exploration or pre-training phase (4 to 6 years old); training phase (7 to 17 years old) and post-training (18 to $23 / 24$ years). All members pay an annuity up to the age of 21 , which includes accident insurance, sports equipment and soccer shoes. All training material is provided by the club.

RSC Academy is largely responsible for detecting and training future "mauve" talents. This is the basis of our training, which includes children from 4 to 13 years old. The Academy has a field of natural grass dimensions $11 \times 11$, a synthetic field with dimensions $11 \times 11$, another synthetic in the dimensions of futsal ( $40 \times 20$ meters) $5 \times 5$, another synthetic field in dimensions $4 \times 4$ with edges, and a field covered in dimensions $8 \times 8$. In addition, it has changing rooms, canteen, video room, coordination room and coaches' locker rooms. There is no food before or during training, only the personal hydration of each child. On the game day, fruit, sandwiches and juice or water are offered after the competition.

The categories are divided into sub 5 to sub 7 , in which $2 \times 2(20 \mathrm{~m}$ by $12 \mathrm{~m})$ are played and trained 3 times a week, from $5 \mathrm{pm}$ to $6: 15 \mathrm{pm}$ on Mondays, Wednesdays and Fridays. In the sub 8 and sub 9 category, $5 \times 5$ $(35 \mathrm{~m}$ by $25 \mathrm{~m})$ is played on the "diamond device" (game system). In the 1st phase, children play with each other; in the 2 nd phase the children start the opposition process (they play against each other): they play $1 \times 1$ games (duel) and perform the driving and dribbling in order to score the goal.

In the sub 10 to sub 12 categories, $8 \times 8(60 \mathrm{~m}$ by $45 \mathrm{~m}$ ) are played in the double diamond or double diamond device. Training sessions are held 4 times a week (Monday to Thursday, from 6:15 pm to 7:45 pm) and a championship game is usually held on Saturday or Sunday, or with weekend tournaments.

Training is divided in a similar way within the club's annual planning, into two parts: 1) The child's individual development (basics - representing a set of individual technical and tactical skills, which a novice player needs to perform right after taking a decision, regardless of the game system at work); 2) The collective tactical aspects (Team Tactics - represents a set of actions for a better functioning of the practitioner in a team, within the game system that acts, while using the "basic elements" already learned, as well as the physical and mental skills). For example, as in a normal training week: Monday and
Wednesday - Basic aspects of learning (Basics), Tuesday and Thursday - Tactical aspects (Team Tactics). And on Saturday the game itself. The competition is regulated by the federation, there is no classification until the end of the sub 12 category.

A training session occurs as follows within the individual development: a warm-up with ball performing kick ups (embassy) through a model or video, or activities in pairs or trios and duels (1x1 game). The analytical form of oriented control, or pass, is used a little; submission and return to calm and a small game (collective). With regard to the Team Tactics development, a warm-up can be performed, which can be ball possession games and soon after, activities seeking the positional game; games of transition and return to calm, then a collective.

There is a philosophy of training and progression of the child at the Training Center. Specific themes are worked out for each category, always aiming at the "RSC Anderlecht profile", to play within the system or scheme adopted by the club, which is $1: 4: 3$ : 3 . Of course, there is flexibility for coaches to take their approaches and use other game systems or models.

\section{DISCUSSION}

The methodological approaches are differentiated with regard to an "elite" club that aims at high performance and federation (base of the pyramid). Each club has its philosophy, its approach. On the other hand, the federation tries to qualify and standardize its way, its method.

For Bayer (1994) methodology is the science that studies the methods, and the path that the teacher / trainer uses to achieve his goals is called method. In the club, the teacher / trainer must know the most varied teaching and training methods in the pursuit of excellence with the practitioners (ROMÃO, BARBOSA, MOREIRA, 2018).

At Anderlecht, for everything described above, the training process for young athletes comes close to an active methodology, where physical, technical and tactical activities are always linked to cognitive issues, always seeking to develop the intelligence and creativity of these individuals. In training, the environment (activities) will always be open, that is, the practitioner will realize that within a problem situation of the game, there will be several choices, and in this context he will have to make an appropriate decision, always trying to get it right, in order to increase its effectiveness (KIELING, 2016; GREBOGGY and SILVA, 2018). 
In the process of forming the RSC Anderlecht, in parallel, internal clinics are developed in order to qualify, evaluate, update and direct the structures and activities within the training center. In addition, there are exchanges with other clubs, such as Borussia Dortmund - Germany and Atalanta - Italy, in which the "philosophy" of each club is presented, with a theoretical and a practical part.

Based on what Reis (1994) and Caldas et al. (2014) stated, "the method brings with it an idea, a direction with the purpose of achieving a purpose (...)". The method implies an orderly process and an integration of thought and action, as well as (unpredictable) reaction, to achieve everything that was previously planned. "The idea of organization also implies planning and re-planning, given the appearance of the reaction, of coherent and cohesive procedures for the integral development of practitioners".

It is verified within the club that, through this internal dynamics and the exchange of external experiences, the subjects directly linked in the execution of the "mauve methodology" are constantly in "dialogue between theory and practice", in search of a continuous evolution, planning and redesigning the way forward for the training center.

Always thinking about the formation of a great athlete, RSC Anderlecht develops a strategy called attention capacity in the formation of this player, which is multipurpose (multifunctional). By definition it is a feature that has different values and uses, with several jobs and many functions.

Multi-functionality stems from curiosity, the desire to learn new things, discover new horizons. It is said that the learning curve is not linear, it progresses quickly at first and then becomes slower and slower. Therefore, it is important to invest in creating multifunctional athletes, providing a maximum acquisition of skills, allowing a greater capacity to solve the various problems inherent in the game. According to Caldas et al., (2012), one of the concerns in training applied at Anderlecht is the activities that stimulate the cognitive processes of athletes, which activate the most varied areas of the human brain through the processes of perception, anticipation, taking decision, attention, concentration, memory, language, learning, among others.

After being taught the game in man-toman marking, sub 5 and sub 7 categories, going through ages sub 8 and sub 9, leading practitioners to a better understanding of the game, technical actions inserted in tactical situations, for example, occupation in the field game to receive and pass the ball; from that moment on, as was said in the method described, in Anderlecht we try to insert a game model from the beginning, worrying about the next categories to come, this shown in figure 01.

Figure 01 - Figure of the game system (double diamond, measures $60 \mathrm{~m} \times 45 \mathrm{~m}$ from the field), in which teams under 10 to under 12 play in the formation at Anderlecht.

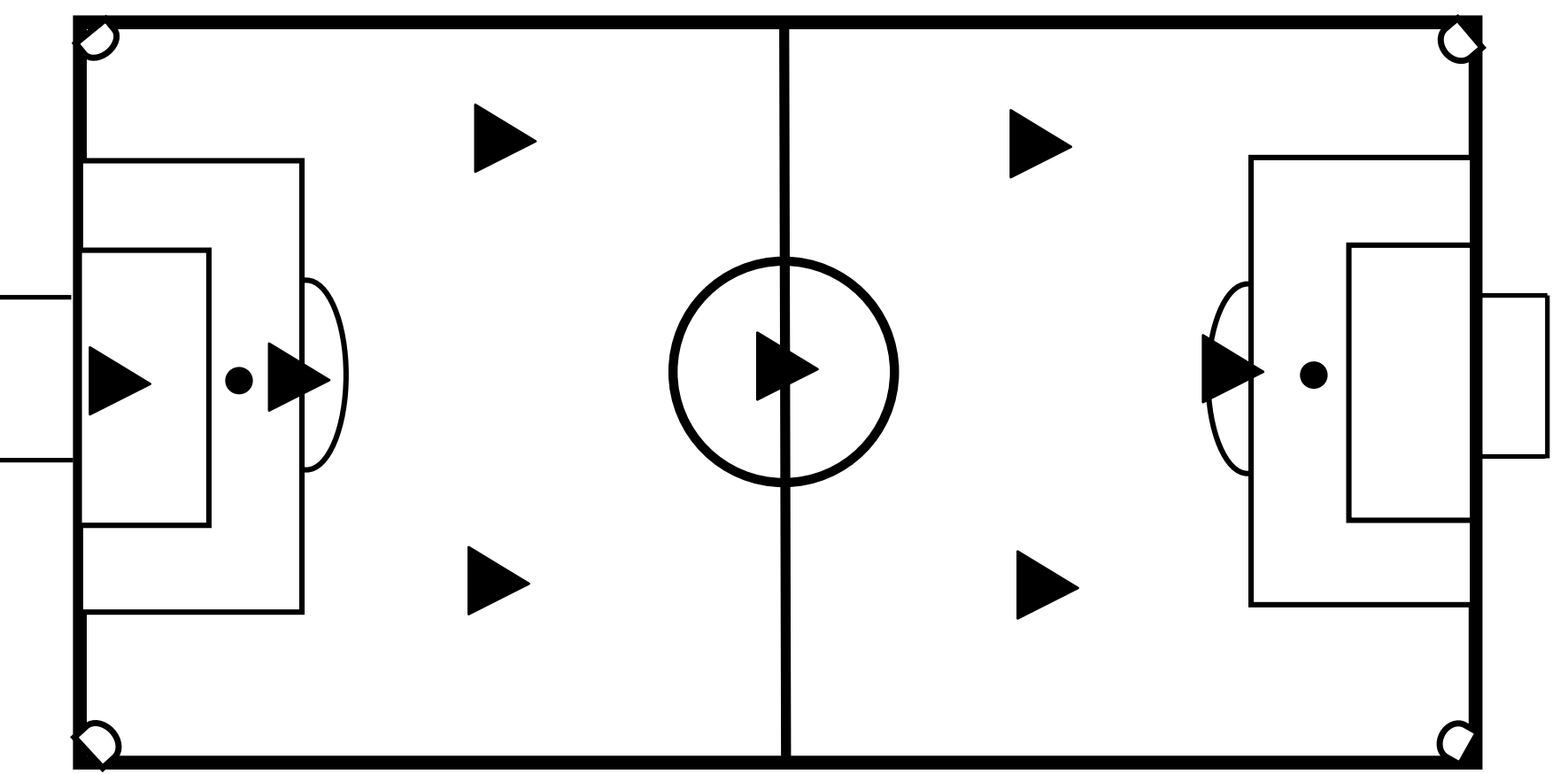


Thus, in the face of great planning that is drawn up and executed within the club, it is believed that there has been a methodological path for teaching soccer in the grassroots categories at Anderlecht: discussions, training, exchanges, innovations, search for knowledge scientific knowledge, materialization of this knowledge, and concern with the training of the new coach. All these parameters make the club become one or one of the forces of Belgian football, raising its level and managing to compete in high level championships against the most varied and very strong teams in Europe.

\section{CONCLUSION}

Working for 11 years in Belgian football, concerns arise due to readings and conversations with some colleagues from Brazil and Europe. Therefore, the opportunity arose to scientifically address the methodological path adopted by the club I work in, publicizing the work of initiation in Anderlecht soccer. I am currently in my seventh season at Anderlecht, I am a coach in the under 11 category $(8 \times 8)$ and a technical assistant in the under 13 male category $(11 \mathrm{x}$ 11 ), but I have already worked in the sub 9 ( $5 x$
5) and sub 10 categories $(8 \times 8)$. In view of everything described and disclosed in this report, it is confirmed that there is a dynamic, transversal methodology within the RSC Anderlecht, which seeks at the end of each cycle an evaluation, redesign and redirection of all methodology that follows in an institution that values the process of initiation and development of the individual in soccer, within a philosophy.

Logically, believing that the "Anderlecht method" is the most correct or the "most correct" is not the objective of this report, but rather to discuss, in the scientific field, what happens in practice, narrowing this distance that exists in our soccer, from little scientific production. Certitude does not move you forward; doubts make you leave the comfort zone and this is also one of the objectives of this study, because getting involved with Science is not just putting into practice what you have studied, it goes far beyond this context: it means always seeking to update with evolution methodological and pedagogical theories, find answers and seek new questions, new doubts.

\section{REFERENCES}

BAYER, C. O ensino dos desportos colectivos. Lisboa: Dinalivros, 1994.

CALDAS, et al. Processos Cognitivos Envolvidos na Prática do Handebol: Aspectos Importantes para Formação de Atletas de Alto Rendimento. Neurobiologia, n. 75, p. 183-193, 2012.

CALDAS, I. S. L. Treinando Handebol. 1 Ed. Eitora da Universidade Federal de Pernambuco, 2014, p.83.

DALLEGRAVE, E. J.; BERNO, C. S.; FOLLE, A. Método situacional: aplicação nos treinamentos técnico-táticos de uma equipe de base do handebol feminino. Corpoconsciência, v. 21, n. 1, 2017.

GREBOGGY, D. L.; SILVA, W. R. A periodização tática sob a justificativa das neurociências: habituação e reestruturação das tomadas de decisão. Revista Brasileira de Futsal e Futebol, v. 10, n. 38, p. 382-389, 2018.

KIELING, T. Nível de motivação em jovens praticantes de futebol. Revista do Centro de Ciências da Sáude - DO CORPO: Ciências e Artes, Universidade de Caxias do Sul, v. 6, n. 1, 2016. 


\section{BELGIUM SOCCER}

REVERDITO, R. S.; SCAGLIA, A. J. Pedagogia do esporte: jogos coletivos de invasão. São Paulo: Phorte Editora, 2009.

REIS, H. H. B. O ensino dos jogos esportivizados na escola. Dissertação (Mestrado em Educação Física) UFSM, Santa Maria, 1994.

ROMÃO, E. J. R.; BARBOSA, P. V. S.; MOREIRA, M. C. Metodologias de ensino para jogos esportivos coletivos na educação física escolar. Revista de Iniciação Científica da Universidade Vale do Rio Verde, v. 7, n. 1, 2018. 